\title{
Molecular prevalence and factors associated with Babesia vogeli infection in dogs in the Cerrado Mato-Grossense region of Brazil
}

\author{
Vanessa Vieira Castro ${ }^{1}$ Eveline da Cruz Boa Sorte Ayres ${ }^{2}$ Darlan Henrique Canei ${ }^{2}$ iD \\ Mariana Elisa Pereira ${ }^{2}$ Valéria Régia Franco Sousa ${ }^{3}$ Cristiane Silva Chitarra ${ }^{2}$ \\ Valéria Dutra ${ }^{3}$ Luciano Nakazato $^{3}$ Arleana do Bom Parto Ferreira de Almeida ${ }^{3^{*}}$ (D)
}

'Programa de Residência Uniprofissional em Medicina Veterinária (PRUMV), Universidade Federal de Mato Grosso (UFMT), Cuiabá, MT, Brasil.

${ }^{2}$ Programa de Pós-graduação em Ciências Veterinárias, Faculdade de Medicina Veterinária, Universidade Federal de Mato Grosso (UFMT), Cuiabá, MT, Brasil.

${ }^{3}$ Faculdade de Medicina Veterinária, Universidade Federal de Mato Grosso (UFMT), 78060-900, Cuiabá, MT, Brasil. E-mail: arleferreira@gmail.com..'Corresponding author.

ABSTRACT: Canine babesiosis is a common haemoparasitosis in Brazil. Caused by parasites of the genus Babesia, it is transmitted by ixodid ticks and affects domestic and wild canids. The objective of this study was to verify the prevalence of Babesia species (spp.) using molecular methods in dogs living in urban and rural areas of Cuiabá, Mato Grosso State, Brazil, and to identify the main factors associated with infection. A total of 407 samples from 407 dogs were evaluated using a polymerase chain reaction (PCR) technique, among which Babesia species (spp.) was amplified in $10(2.5 \%)$. Although, no statistical association was found among the variables studied ( $p>0.05)$, greater positivity was observed in dogs $<1$ year of age, male sex, those with free access to the street, and the presence of ticks. PCR samples positive for Babesia spp. were submitted to sequencing and compared in GenBank and exhibited a high degree of similarity with Babesia vogeli sequences. Key words: babesiosis, molecular identification, Cuiaba.

Prevalência molecular e fatores associados à infecção por Babesia vogeli em cães do cerrado Mato-Grossense

RESUMO: Babesiose canina é uma hemoparasitose comum no Brasil. Causada por parasitos do gênero Babesia, é transmitida por carrapatos ixodideos e acomete canídeos domésticos e silvestres. O objetivo deste trabalho foi verificar a prevalência molecular da infecção por Babesia spp. em cães residentes em áreas urbanas e rurais do município de Cuiabá, estado de Mato Grosso, Brasil, e relacionar os principais fatores associados à infecção. Para a pesquisa foram avaliados 407 cães usando a PCR. Das 407 amostras analisadas, 10 (2,5\%) amplificaram DNA de Babesia spp. Não foi observada associação estatística entre as variáveis pesquisadas ( $>>0,05)$, porém observou-se maior positividade em cães com idade inferior a um ano, machos, com livre acesso à rua e com a presença de carrapatos. Amostras positivas nas PCRs para Babesia spp. foram submetidas a sequenciamento e comparadas no GenBank, mostrando alto grau de similaridade com as sequências de B. vogeli. Palavras-chave: babesiose, identificação molecular, Cuiabá.

First detected by PASSOS et al. (2005) in Minas Gerais, Brazil, using a polymerase chain reaction (PCR) technique, Babesia is known to cause babesiosis in dogs in Brazil (SILVA et al., 2016). It has also been reported in France, Australia, Japan, South Africa, and the United States. Rhipicephalus sanguineus sensu lato is the biological vector of this protozoan species in Brazil (PASSOS et al., 2005; SCHOEMAN, 2009).

Among Babesia species (spp.), Babesia vogeli is the least pathogenic, and usually causes mild disease in adult dogs, but more severe illness in puppies, immunosuppressed dogs, or animals coinfected with other pathogens. Weakness, anorexia, paleness of the mucosas, fever, lymphadenomegaly, and splenomegaly are common clinical signs of the disease, similar to infections caused by other Babesia spp. (AZMI et al., 2017; WANG et al., 2018).

For many years, microscopic detection of the parasite using the blood smear stain technique has been considered the gold standard for the diagnosis of acute babesiosis. However, the low sensitivity of the technique makes detection difficult in cases of low parasitemia. Molecular techniques, such as PCR, have been applied and have shown to be more efficient in detecting and identifying Babesia spp. infections due to their high specificity and sensitivity (MTSHALI \& MTSHALI, 2013; DAVITKOV et al., 2015). However, this sensitivity is decreased in samples obtained from asymptomatic dogs naturally 
infected with Babesia in the chronic disease phase when low fluctuations in parasitaemia are observed (IRWIN, 2009; SOUSA et al., 2013).

Based on these data and the few studies investigating babesiosis in the region, the present study was designed to verify the prevalence of Babesia spp. in the city of Cuiabá-MT, Brazil, and to identify the main factors associated with the infection, in addition to identifying the circulating species.

A total of 407 domiciled dogs evaluated in a cross-sectional study for visceral leishmaniasis conducted in endemic, urban, and rural areas in the municipality of Cuiabá, Mato Grosso State, Brazil (ALMEIDA et al. 2013) were used in the research. Sampling was calculated using an $8 \%$ prevalence rate for canine babesiosis (O'DWYER et al., 2009) based on the canine population of 64,290 from data provided by the Cuiabá Municipal Health Department, and an acceptable error rate of $5 \%$, estimating a minimum of 400 dogs.

Owners were required to provide informed consent allowing enrollment of their dogs in the study. After the dogs were evaluated for body condition score, lymphadenopathy, and eye and dermatological changes, a questionnaire including this information was completed. Factors associated with infection, such as sex, race, age, street access, presence of ticks, origin, displacement to other regions, rural or urban residence area, permanence indoors, environment fumigation, and the presence of vegetation were also addressed in the questionnaire.

Blood samples $(5 \mathrm{ml})$ were collected from the cephalic or jugular vein and stored in tubes containing ethylenediamine tetraacetic acid (EDTA) for molecular analysis. Extraction of DNA from these samples was performed using the phenol/chloroform/ isoamyl alcohol method, according to a protocol described by ALMEIDA et al. (2013). A pair of Babesia oligonucleotides was used for PCR (forward, 5'-CCG TGC TAA TTG TAG GGC TAA TAC A-3' and reverse, 5'-GCT TGA AAC ACT CTA RTT TTC TCA AAG-3') to amplify a region of approximately 550 base pairs of the 18S ribosomal RNA (rRNA) gene, according to ALMEIDA et al. (2012a). The amplified products were separated using $1.5 \%$ agarose gel electrophoresis, stained with Gel Red (Biotium) and visualized on an ultraviolet transilluminator (UV$300 \mathrm{~nm}$ ). Amplified fragments were subjected to sequencing using the Sanger method on an automated sequencer (ABI-3500, Applied Biosystems, Foster City, CA, USA).

The data obtained were transferred to a database and statistically analyzed using Epilnfo version 3.3.2 software (Centers for Disease Control $\&$ Prevention, Atlanta, GA, USA), and evaluated using chi-squared or Fisher's exact test to test the association between independent variables and the presence of Babesia spp. DNA, considering a significance level of 5\%. All variables were tested in multivariate analysis.

The specific fragment of the $18 \mathrm{~S}$ rRNA gene from Babesia spp. was detected in 2.5\% (10 of 407 [95\% confidence interval [CI] $1.0-4.2 \%$ ) of the samples analysed. All positive amplicons for Babesia spp. were purified, sequenced, and compared in GenBank, which revealed 99\% identity with the following deposits: KT323936.1, KT323935.1, KU710803.1, EF052627.1, all of which were identified as B. vogeli.

The prevalence of infection determined in the present study was relatively low, and is in agreement with other studies from different regions of Brazil, such as MELO et al. (2016) in Mato Grosso $(3.1 \%)$, SOUZA et al. (2013) in Mato Grosso do Sul (3.3\%), SILVA et al. (2012) in Maranhão (3.3\%), RAMOS et al. (2010) in Pernambuco (7.3\%), O'DWYER et al. (2009) in São Paulo (8\%), COSTAJÚNIOR et al. (2012) in Minas Gerais (10.8\%), RIBEIRO et al. (2017) in Paraná (10.9\%), PAULINO et al. (2018) in Rio de Janeiro (14\%), MORAES et al. (2015) in Pará (15.7\%).

To our knowledge, the present study was the first to estimate the prevalence of infection by Babesia spp in the city of Cuiabá - Mato Grosso, with evidence of autochthonous cases, because all positive amplicons were from animals born in the city and without previous displacement to other regions (Table 1). However, this is not the first molecular description of $B$. vogeli reported in the city. SPOLIDORIO et al. (2011) detected the presence of this piroplasma in six sick dogs treated at veterinary hospitals. In a study involving blood donor dogs admitted to a veterinary hospital in the same capital, SEABRA DA CRUZ et al. (2017) detected infection by $B$. vogeli and stressed the importance of more sensitive and specific diagnostic methods, such as PCR, and screening animals for this purpose. In a prevalence study in Poconé, a municipality located $100 \mathrm{~km}$ from Cuiabá, Pantanal Matogrossense region, MELO et al. (2016) reported dogs and ticks parasitized with the same species.

The detection of $B$. vogeli in urban and rural dogs in the present study was probably due to the predominance of Rhipicephalus sanguineus, the main tick species observed in the region (ALMEIDA et al., 2012b; MELO et al., 2016), and the unique known natural vector 
Table 1 - Univariate and multivariate analysis of variables considered associated with Babesia vogeli infection in dogs from Cuiabá, Mato Grosso.

\begin{tabular}{|c|c|c|c|c|}
\hline Variables & $\mathrm{N}$ & Positive (\%) & Univariate Analysis & Multivariate Analysis \\
\hline & & & $p / \mathrm{OR}(\mathrm{CI})$ & $p$ \\
\hline \multicolumn{5}{|c|}{ 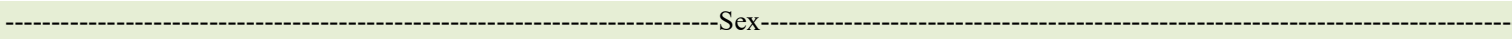 } \\
\hline Male & 221 & $7(3.2)$ & 0.249 & 0.31 \\
\hline Female & 186 & $3(1.6)$ & $0.50(0.11-1.7)$ & \\
\hline \multicolumn{5}{|c|}{ } \\
\hline CRD & 77 & $2(2.6)$ & 0.59 & 0.93 \\
\hline SRD & 330 & $8(2.4)$ & $1.07(0.33-4.74)$ & \\
\hline \multicolumn{5}{|c|}{ 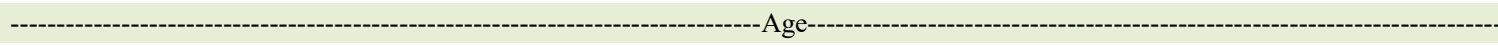 } \\
\hline Indefinite age & 23 & $0(0.0)$ & 0.56 & 0.58 \\
\hline$<1$ year & 57 & $3(5.3)$ & & \\
\hline 1-3years & 152 & $3(2.0)$ & & \\
\hline 3-6years & 112 & $3(2.7)$ & & \\
\hline$>6$ years & 63 & $1(1.6)$ & & \\
\hline \multicolumn{5}{|c|}{ - } \\
\hline No & 131 & $2(1.5)$ & 0.32 & 0.40 \\
\hline Yes & 276 & $8(2.9)$ & $1.92(0.49-5.59)$ & \\
\hline \multicolumn{5}{|c|}{ 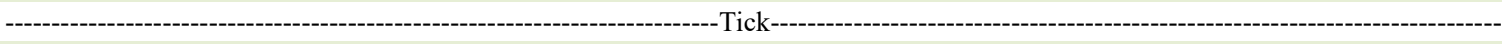 } \\
\hline No & 74 & $2(2.7)$ & 0.56 & 0.88 \\
\hline Yes & 333 & $8(2.4)$ & $0.88(0.22-2.66)$ & \\
\hline \multicolumn{5}{|c|}{ 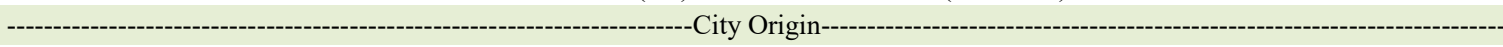 } \\
\hline Cuiabá & 378 & $10(2.6)$ & 0.47 & 0.37 \\
\hline Others & 29 & $0(0.0)$ & $0.92(0.90-0.95)$ & \\
\hline \multicolumn{5}{|c|}{ 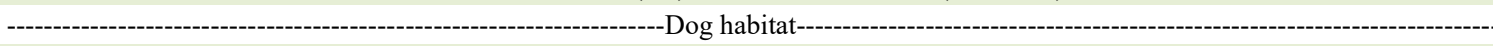 } \\
\hline Indoor & 6 & $0(0.0)$ & 0.86 & 0.69 \\
\hline Outdoor & 401 & $10(2.5)$ & $0.98(0.97-0.99)$ & \\
\hline \multicolumn{5}{|c|}{ 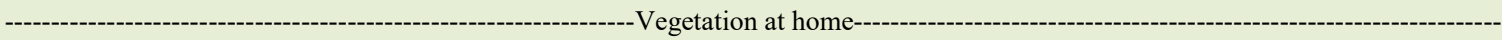 } \\
\hline No & 70 & $1(1.4)$ & 0.46 & 0.54 \\
\hline Yes & 337 & $9(2.7)$ & $1.89(0.31-3.10)$ & \\
\hline \multicolumn{5}{|c|}{ 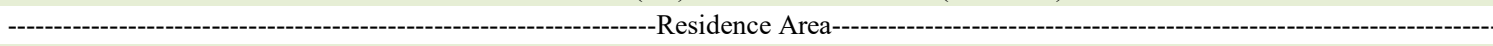 } \\
\hline Rural Area & 112 & $2(1.8)$ & 0.45 & 0.59 \\
\hline Urban Area & 295 & $8(2.7)$ & $0.65(0.21-2.61)$ & \\
\hline \multicolumn{5}{|c|}{ - } \\
\hline No & 342 & $9(2.6)$ & 0.50 & 0.60 \\
\hline Yes & 65 & $1(1.5)$ & $0.57(0.34-3.19)$ & \\
\hline
\end{tabular}

N, number of animals; OR, odds ratio; CI, confidence interval; CRD - With defined Breed; SRD - Without defined Breed;

of this protozoan (DANTAS-TORRES, 2008). Results of this experiment indicated that animals raised in urban and rural environments had a similar prevalence of infection, and no significant differences were reported $(\mathrm{p}>0.05)$. Thus, we speculated that animals raised under conditions similar to those in the present study have the same risk for acquiring an infection.

Considered to be less pathogenic, $B$. vogeli manifests subclinically or with only mild disease, exhibiting greater severity in splenectomized animals and puppies (SCHOEMAN, 2009; WANG et al., 2018). Of the infected dogs, seven (58.3\%) exhibited some clinical sign at the time of data and sample collection including lymphadenomegaly, progressive weight loss, petechiae, alopecia, and/or conjunctivitis. However, the stage of infection was unknown and other tick-borne diseases could not be excluded (WANG et al., 2018). The other three positive dogs 
were subclinical. In a survey conducted in Croatia, a higher prevalence of $B$. vogeli was observed in dogs with subclinical infection compared to those with clinical signs (BECK et al., 2009). The presence of $B$. vogeli in clinically healthy dogs in our study corroborates the available literature, which considers $B$. vogeli to be the least pathogenic strain that causes relatively mild disease, usually subclinical infection (BECK et al., 2009; IRWIN 2009; SCHOEMAN, 2009; IONITA et al., 2011; WANG et al., 2018).

Regarding factors associated with infection (Table 1); although, male and defined-breed dogs exhibited higher positivity, variables, such as sex and breed, revealed no statistical association with Babesia spp. infection as COSTA-JÚNIOR et al. (2009), SILVA et al. (2012), ARAÚJO et al. (2015), and PAULINO et al. (2018) reported in their studies.

Although, no statistical difference was observed in relation to age and infection with Babesia spp., the frequency of positive dogs was higher in the group of animals $<1$ year of age (5.3\%). Accounting for factors such as immature immune system associated with the stress of adapting to a new environment and a new diet, young and weaned dogs are actually more susceptible to disease (PAULINO et al., 2018). However, some reports in the literature described a higher prevalence in adult dogs (GUIMARÃES et al. 2009; ARAÚJO et al., 2015; SILVA et al. 2016), attributing senility to greater infestation and time to vector exposure, thus increasing the possibility of acquiring the infection.

Tick parasitism was evident in $>80 \%$ of the dogs in this study (Table 1) and, among the 10 PCRpositive animals, eight were tick-infested at the time of biological material collection. Although, this risk factor is directly related to positivity for babesiosis, evidence supporting this relationship did not reach statistical significance in the present investigation $(p=0.88)$. These results may be explained by the low number of infected dogs, which may have been insufficient to infer a relationship between infection and tick infestation, a fact described by O'DWYER et al. (2009), who also reported greater tick infestation in infected dogs.

No statistically significant association between free access to the street, indoor or outdoor dogs, and the presence of vegetation at home and infection with Babesia spp. was observed (Table 1). Dogs raised outdoors and with street access tend to be bred less carefully by the guardian, thus not performing adequate parasite control (FONSECA et al., 2017). The presence of vegetation also facilitates exposure to ixodids, favoring the occurrence of haemoparasites, mainly in dogs raised in backyard houses (SOARES et al., 2006). Although, environmental control of ticks is performed by some owners, this important prophylactic measure was not statistically significant in this study, corroborating the results of SILVA et al. (2012). ADASZEK et al. (2011) highlighted that properly performed ectoparasite prophylaxis considerably limits Babesia spp. infection.

In conclusion, the present study demonstrated that the prevalence of babesiosis in naturally infected dogs, based on molecular data, is low in Cuiabá city, with $B$. vogeli being the circulating agent in both urban and rural regions, demonstrating a similar prevalence. The detection of this piroplasma in the Brazilian cerrado should be brought to the attention of veterinarians and tutors so that effective measures can be implemented to control canine babesiosis.

\section{ACKNOWLEDGEMENT}

This study was financed in part by the Coordenação de Aperfeiçoamento de Pessoal de Nível Superior (CAPES), Brasil - Finance code 001, FAPEMAT - Fundação de Amparo a Pesquisa do Estado de Mato Grosso. The authors are grateful to the MEC for the Vanessa Vieira Castro Uniprofessional Residency in Veterinary Medicine scholarship.

\section{BIOETHICS AND \\ COMMITTEE APPROVAL}

BIOSECURITY

This study was approved by the Ethics Committee for the Use of Animals of the Universidade Federal de Mato Grosso (UFMT), Brazil, under protocol number 23108.019868/099.

\section{DECLARATION OF CONFLICT OF INTERESTS}

The authors declare no conflict of interest. The founding sponsors had no role in the design of the study; in the collection, analyses, or interpretation of data; in the writing of the manuscript, and in the decision to publish the results.

\section{AUTHORS' CONTRIBUTIONS}

All authors contributed equally for the conception and writing of the manuscript. All authors critically revised the manuscript and approved of the final version.

\section{REFERENCES}

ADASZEK, L. et al. The factors affecting the distribution of babesiosis in dogs in Poland. Veterinary Parasitology, Netherlands, v.181, n2-4, p.160-165, 2011. Available from: $<$ https:// www.sciencedirect.com/science/article/pii/S0304401711002615>. Accessed: Mar. 14, 2019. doi: 10.1016/j.vetpar.2011.03.059.

ALMEIDA, A.B.P.F. et al. Seroepidemiological survey of canine leishmaniasis in endemic areas of Cuiabá, State of Mato Grosso. Revista da Sociedade Brasileira de Medicina Tropical, 
Uberaba, v.42, n.4, p.156-159, 2009. Available from: $<$ http:// www.scielo.br/scielo.php?script $=$ sci arttext\&pid $=$ S0037$86822009000200012 \& \operatorname{lng}=$ pt\&tlng=pt $>$. Accessed: Mar. 02, 2019. doi: $10.1590 / \mathrm{S} 0037-86822009000200012$.

ALMEIDA, A.B.P.F. et al. Prevalence and epidemiology of visceral leishmaniasis in dogs and humans in the city Cuiaba, Mato Grosso, Brazil. Ciência Rural, Santa Maria, v.40, n.7, p.1610-1615, 2010. Available from: <http://www.scielo.br/scielo php?script $=$ sci_arttext\&pid=S0103-84782010000700020\&lng $=\mathrm{pt} \& \operatorname{lng}=\mathrm{pt}>$. Accessed: Mar. 02, 2019. doi: 10.1590/S010384782010005000102 .

ALMEIDA, A.B.P.F. et al. Canine visceral leishmaniasis: seroprevalence and risk factors in Cuiabá, Mato Grosso, Brazil. Revista Brasileira de Parasitologia Veterinária, Jaboticabal, v.21, n.4, p.359-365, 2012a. Available from: <http:// www.scielo.br/scielo.php?script $=$ sci arttext\&pid $=\mathrm{S} 1984$ $29612012005000005 \& \operatorname{lng}=$ en\&nrm $=$ iso\&tlng $=$ en $>$. Accessed: Mar. 02, 2019. doi: 10.1590/S1984-29612012005000005.

ALMEIDA, A.B.P.F. et al. Ehrlichia canis and Anaplasma platys in ticks of dogs in Cuiabá, Mato Grosso. Semina: Ciências Agrárias, Londrina, v.33, n.3, p.1123-1126, 2012b. Available from: <https:// www.redalyc.org/html/4457/445744113034/>. Accessed: Mar. 02, 2019. doi: 10.5433/1679-0359.2012v33n3p1123.

ALMEIDA, A.B.P.F. et al. Canine visceral leishmaniasis: diagnostic approaches based on polymerase chain reaction employing different biological samples. Diagnostic Microbiology and Infectious Disease, New York, v.76, n.3, p.321-324, 2013. Available from: <https://www.sciencedirect.com/science/ article/pii/S0732889313001867>. Accessed: Mar. 26, 2019. doi: 10.1016/j.diagmicrobio.2013.03.017.

BECK, R. et al. Diversity of Babesia and Theileria species in symptomatic and asymptomatic dogs in Croatia. International Journal for Parasitoloy, Oxford, v.39, p.843-848, 2009. Available from: <https:/www.sciencedirect.com/science/article/ pii/S0020751909000277?via\%3Dihub>. Accessed: Mar. 14, 2019. doi: 10.1016/j.ijpara.2008.12.005.

COSTA-JÚNIOR, L.M. et al. Canine babesiosis caused by Babesia canis vogeli in rural areas of the State of Minas Gerais, Brazil and factors associated with its seroprevalence. Research in Veterinary Science, Oxford, v.86, p.257-260, 2009. Available from: $<$ https:/ www.ncbi.nlm.nih.gov/pubmed/18723199>. Accessed: Mar. 18, 2019. doi: 10.1016/j.rvsc.2008.07.002.

COSTA-JÚNIOR, L.M. Use of a Real Time PCR for detecting subspecies of Babesia canis. Veterinary Parasitology, Netherlands, v.188, p.160-163, 2012. Available from: <https:// www.ncbi.nlm.nih.gov/pubmed/22516643>. Accessed: Mar. 07, 2019. doi: 10.1016/ j.vetpar.2012.03.015.

DANTAS-TORRES, F. Causative agents of canine babesiosis in Brazil. Preventive Veterinary Medicine, Netherlands, v.83, n.2, p.210-211, 2008. Available from: $<$ https://www.sciencedirect.com/ science/article/pii/S0167587707002036?via\%3Dihub>. Accessed: Feb. 26, 2019. doi: 10.1016/j.prevetmed.2007.03.008.

DAVITKOV, D. et al. Clinical babesiosis and molecular identification of Babesia canis and Babesia gibsoni infections in dogs from Serbia. Acta Veterinaria Hungarica, Budapest, v.63, p.199-208, 2015. Available from: <https://www.ncbi.nlm.nih. gov/pubmed/26051258>. Accessed: Jul. 08, 2019. doi: 10.1556/ AVet.2015.017.

FONSECA, J.P. et al. Hematological parameters and seroprevalence of Ehrlichia canis and Babesia vogeli in dogs. Ciência Animal Brasileira, Goiânia, v.18, p.1-9, 2017. Available from: $\quad<$ http://www.scielo.br/scielo.php?pid=S180968912017000100301\&script $=$ sci_arttext $>$. Accessed: Mar. 11, 2019. doi: 10.1590/1089-6891v18e-36095.

GUIMARÃES, A.M. et al. Factors associated the seropositivity for Babesia, Toxoplasma, Neospora e Leishmania in dogs attended at nine veterinary clinics in the municipality of Lavras, MG. Revista Brasileira de Parasitologia Veterinária, Jaboticabal, v.18, n.1, p.49-53, 2009. Available from: <http://www.scielo. br/scielo.php?pid=S1984-29612009000500009\&script $=$ sci abstract\&tlng=pt $>$. Accessed: Mar. 15, 2019. doi: 10.4322/ rbpv.018e1009.

IONITA, M. et al. Canine babesiosis in Romania due to Babesia canis and Babesia vogeli: a molecular approach. Parasitology Research, Lawrence, v.110, n.5, p.16591664, 2012. Available from: <https://link.springer.com/ article/10.1007/s00436-011-2683-y>. Accessed: Mar. 28, 2019. doi: 10.1007/s00436-011-2683-y.

IRWIN, P.J. Canine babesiosis: from molecular taxonomy to control. Parasites \& Vectors, v.2, n.1, p.1-4, 2009. Available from: $<$ https://www.ncbi.nlm.nih.gov/pmc/articles/PMC2679396/>. Accessed: Mar. 13, 2019. doi: 10.1186/1756-3305-2-S1-S4.

MELO, A.L.T. et al. A survey of tick-borne pathogens in dogs and their ticks in the Pantanal biome, Brazil. Medical and Veterinary Entomology, Oxford, v.30, p.112-116, 2016. Available from: $<$ https://onlinelibrary.wiley.com/doi/full/10.1111/mve.12139>. Accessed: Mar. 20, 2019. doi: 10.1111/mve.12139.

MTSHALI, M.S.; MTSHALI, P.S. Molecular diagnosis and phylogenetic analysis of Babesia bigemina and Babesia bovis hemoparasites from cattle in South Africa. BMC Veterinary Research, London, v.9, p.154, 2013. Available from: <https:// www.ncbi.nlm.nih.gov/pubmed/23927555>. Accessed: Mar. 7, 2019. doi: 10.1186/1746-6148-9-154.

O'DWYER, L.H. et al. Babesia spp. infection in dogs from rural areas of São Paulo State, Brazil. Revista Brasileira de Parasitologia Veterinária, Jaboticabal, v.18, n.2, p.23-26, 2009. Available from: <http://www.scielo.br/scielo.php?pid=S198429612009000200005\&script $=$ sci arttext $>$. Accessed: Mar. 7, 2019. doi: $10.4322 /$ rbpv. 01802005 .

PASSOS, L.M.F. et al. First molecular detection of Babesia vogeli in dogs from Brazil. Veterinary Parasitology, Netherlands v.127, n.1, p.81-85, 2005. Available from: <http://www.scielo. br/scielo.php? script $=$ sci_nlinks\&ref $=000053 \&$ pid $=$ S 1984 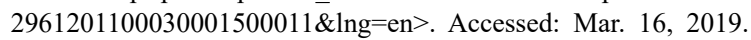 doi: $10.1016 /$ j.vetpar.2004.07.028.

PAULINO, G.P. et al. Molecular epidemiology of Babesia vogeli in dogs from the South eastern region of Rio de Janeiro, Brazil. Veterinary Parasitology, Netherlands, v.13, p.160-165, 2018. Available from: <https://www.sciencedirect.com/science/ article/pii/S2405939018300558>. Accessed: Mar. 20, 2019. doi: 10.1016/j.vprsr.2018.06.004. 
RAMOS, R. et al. Molecular survey and genetic characterization of tick-borne pathogens in dogs in metropolitan Recife (northeastern Brazil). Parasitology Research, Lawrence, v.107, n.5, p.1115-1120,2010. Available from: <https://www.ncbi.nlm.nih. gov/pubmed/20680344>. Accessed: Mar. 15, 2019. doi: 10.1007/ s00436-010-1979-7.

RIBEIRO, C.M. et al. Molecular epidemiology of Anaplasma platys, Ehrlichia canis and Babesia vogeli in stray dogs in Paraná, Brazil. Pesquisa Veterinária Brasileira, Rio de Janeiro, v.37, n.2, p.129-136, 2017. Available from: <http://www.scielo.br/scielo. php?pid=S0100-736X2017000200129\&script $=$ sci_arttext $>$. Accessed: Mar. 16, 2019. doi: 10.1590/s0100-736x2017000200006.

SCHOEMAN, J.P. Canine babesiosis. Onderstepoort Journal of Veterinary Research, Pretoria, v. 76, n. 1, p. 59-66, 2009. Available from: <http://www.scielo.org.za/scielo.php?script=sci_arttext\&pid $=$ S0030-24652009000100014 $>$. Accessed: Mar 15, 2019.

SEABRA DA CRUZ, F.A.C. et al. Occurrence of Leishmania chagasi, Trypanosoma cruzi, Babesia canis vogeli, Anaplasma platys, and Ehrlichia canis in canine blood donors. Semina: Ciências Agrárias, Londrina, v.38, n.1, p.295-300, 2017. Available from: $\quad<$ https://www.redalyc.org/html/4457/445749994044>. Accessed: Mar. 15, 2019. doi: 10.5433/1679-0359.2017v38n1p295.

SILVA, A.B. et al. Detecção molecular de Babesia canis vogeli em cães e em Rhipicephalus sanguineus na mesorregião do Oeste Maranhense, Nordeste Brasileiro. Ciência Animal Brasileira, Goiânia, v.13, n.3, p.388-395, 2012. Available from: <https://www. revistas.ufg.br/vet/article/view/18439>. Accessed: Mar. 12, 2019. doi: 10.5216/cab.v13i3.18439.

SILVA, V.C.L. et al. Parasitological and molecular detection of Babesia canis vogeli in dogs of Recife, Pernambuco and evaluation of risk factor associated. Semina: Ciências Agrárias, Londrina, v.37, n.1, p.163-172, 2016. Available from: <http://www.uel.br/ revistas/uel/index.php/semagrarias/article/view/20338>. Accessed: Mar. 03, 2019. doi: 10.5433/1679-0359.2016v37n1p163.

SOARES, A.O. et al. Avaliação ectoparasitológica e hemoparasitológica em cães criados em apartamentos e casas com quintal na cidade de Juiz de Fora, MG. Revista Brasileira de Parasitologia Veterinária, Jaboticabal, v.15, n.1, p.1316, 2006. Available from: <http://www.redalyc.org/articulo. oa?id=397841457003> . Accessed: Mar. 22, 2019.

SOUZA, K.C.M. et al. Molecular and serological detection of tick-borne pathogens in dogs from in endemic area for Leishmania infantum in Mato Grosso do Sul, Brazil. Revista Brasileira de Parasitologia Veterinária, Jaboticabal, v.22, n.4, p.525-531, 2013. Available from: <http://www.scielo.br/scielo.php?pid=S198429612013000400525\&script $=$ sci arttext $>$. Accessed: Mar. 20, 2019. doi: 10.1590/S1984-29612013000400012.

SPOLIDORIO, M.G. et al. Molecular detection of Hepatozoon canis and Babesia canis vogeli in domestic dogs from Cuiabá, Brazil. Revista Brasileira de Parasitologia Veterinária, Jaboticabal, v.20, n.3, p.253-255, 2011. Available from: <http://www.scielo. br/scielo.php?pid=S1984-29612011000300015\&script $=$ sci arttext>. Accessed: Mar. 19, 2019. doi: 10.1590/S198429612011000300015.

WANG, J. et al. First description of the pathogenicity of Babesia vogeli in experimentally infected dogs. Veterinary Parasitology, Netherlands, v.253, p.1-7, 2018. Available from: $\quad<$ https://www.sciencedirect.com/science/article/pii/ S0304401718300785?via\%3Dihub>. Accessed: Mar. 13, 2019. doi: 10.1016/j.vetpar.2018.02.028. 